\title{
Pengaruh Kepemimpinan Dan Motivasi Kerja Terhadap Kinerja Karyawan Pada Koperasi Bmt El-Raushan Tangerang
}

\author{
Suwanto \\ Dosen Fakultas Ekonomi Universitas Pamulang \\ Email:dosen01813@unpam.ac.id
}

\begin{abstract}
ABSTRAK
Penelitian ini bertujuan untuk mengetahui pengaruh kepemimpinan dan motivasi kerja terhadap kinerja karyawan pada Koperasi BMT EL-RAUSHAN. Pengumpulan data dilakukan dengan menyebar kuesioner kepada 100 karyawan.

Metode yang digunakan dalam penelitian ini adalah metode deskriptif dengan pendekatan asosiatif dengan tehnik pengambilan sampel probability sampling. Metode analisis data menggunakan regresi, determinasi serta pengujian hipotesis secara simultan dan secara parsial.

Hasil penelitian ini adalah kepemimpinan berpengaruh positif dan signifikan terhadap kinerja karyawan sebesar 33,1\%. Uji hipotesis secara parsial diperoleh $\mathrm{t}$ hitung $>\mathrm{t}$ tabel atau $(6,963>1,984)$, sehingga $\mathrm{H}_{0}$ ditolak dan $\mathrm{H}_{1}$ diterima artinya terdapat pengaruh positif dan signifikan antara kepemimpinan terhadap kinerja karyawan pada Koperasi BMT EL-RAUSHAN. Motivasi kerja berpengaruh positif dan signifikan terhadap kinerja karyawan sebesar 41,2\%. Uji hipotesis secara parsial diperoleh $\mathrm{t}$ hitung $>\mathrm{t}$ tabel atau $(8,294>1,984)$ sehingga $\mathrm{H}_{0}$ ditolak dan $\mathrm{H}_{2}$ diterima artinya terdapat pengaruh positif dan signifikan antara motivasi kerja terhadap kinerja karyawan pada Koperasi BMT EL-RAUSHAN. Uji hipotesis simultan kepemimpinan dan motivasi kerja berpengaruh positif dan signifikan terhadap kinerja karyawan dengan koefisien determinasi sebesar $48,2 \%$, sedangkan sisanya sebesar $51,8 \%$ dipengaruhi faktor lain. Uji hipotesis diperoleh nilai $F$ hitung $>F$ tabel atau $(45,122>2,700)$, dengan demikian Ho ditolak dan $\mathrm{H}_{3}$ diterima. Artinya terdapat pengaruh positif dan signifikan secara simultan antara kepemimpinan dan motivasi kerja terhadap kinerja karyawan pada Koperasi BMT EL-RAUSHAN.
\end{abstract}

Kata Kunci : Kemepimpinan, Motivasi Kerja dan Kinerja Karyawan. 


\section{PENDAHULUAN}

Undang-Undang Republik Indonesia No. 25 Tahun 1992 tentang perkoperasian menegaskan bahwa : Koperasi Indonesia adalah badan usaha yang beranggotakan orang seorang atau badan hukum koperasi dengan melandaskan kegiatannya berdasarkan prinsip koperasi sekaligus sebagai gerakan ekonomi rakyat yang berdasar azas kekeluargaan. Koperasi disini dalam kaitannya dengan demokrasi ekonomi adalah sebagai organisasi atau lembaga modern yang mempunyai tujuan, sistem pengolahan, tertib organisasi dan mempunyai azas serta sendi-sendi dasar.

Data empiris Provinsi Banten sebagai provinsi yang sedang giatgiatnya mengembangkan industri usaha kecil menengah sedang dalam trend laju pertumbuhan yang sangat baik khususnya dalam bidang perekonomian dan juga perkoperasian. Angka pertumbuhan ekonomi Provinsi Banten tertinggi terjadi pada tahun 2012, yaitu sebesar $6,42 \%$, dan terendah pada tahun 2015, sebesar 5,65\%. Dari data tersebut juga terlihat terjadinya kenaikan pertumbuhan ekonomi di Provinsi Banten dari tahun 2008 ke 2012, naik sebesar 0,635\%, kemudian kembali menurun kembali pertumbuhan ekonomi ditahun 2013 dengan selisih $0,31 \%$. Terjadi fluktuasi hingga tahun 2015 menjadi tahun dimana pertumbuhan ekonomi Provinsi Banten terkecil di delapan tahun belakangan ini setiap tahunnya. Dalam bidang perkoperasian dengan luas wilayah yang cuma $9.663 \mathrm{~km} 2$ ini Provinsi Banten terbilang maju, setidaknya data dinas koperasi sampai tahun 2015 menunjukkan ada 10.072 koperasi yang tersebar di 8 kabupaten dan kota, dari jumlah tersebut 4.057 unit koperasi adalah koperasi aktif. Dinas Koperasi dan UKM terus mengupayakan program pembinaan dan fasilitasi koperasi di Provinsi Banten. Dari jumlah yang banyak tersebut Dinas Koperasi dan UKM Provinsi Banten terus berupaya agar koperasi dapat mensejahterakan anggotanya dan mempu membina dan mengembangkan UKM (Sumber: BPS Provinsi Banten 2015).

Kondisi ideal koperasi sebagai wadah ekonomi kerakyatan dengan integrasi visi pembangunan ekonomi dan sosialnya yang begitu kuat mampu berperan optimal dalam berkontribusi meningkatkan pertumbuhan pembangunan. Dengan jumlah koperasi yang sangat banyak tersebut tentunya kontribusinya sangat diharapkan dalam mendorong kesejahteraan anggota dan juga para pelaku UKM dan Koperasi dapat berperan dalam meningkatkan kesejahteraan, pendapatan, kemampuan menghadapi kehidupan bagi para anggotanya dan masyarakat pada umumnya.

Koperasi sebagai suatu badan usaha bersama yang bergerak di bidang perekonomian, beranggotakan orang seorang atau badan hukum koperasi atas dasar persamaan hak dan kewajiban melakukan suatu usaha di bidang ekonomi memiliki tujuan yang berorientasi pada kebutuhan para anggotanya, sama halnya dengan koperasi.

Sumber daya manusia memegang peranan penting dalam 
setiap pengelolaan koperasi. Dalam hal ini bahwa sumber daya manusia adalah kunci utama yang harus dapat perhatian penuh dengan semua kebutuhannya. Sumber daya manusia adalah penggerak koperasi sehingga banyak dipengaruhi oleh para pesertanya (partisipannya). Keanggotaan sumber daya manusia dalam koperasi diatur dengan adanya pemberian wewenang dan tanggung jawab dalam pengelolaan kegiatan.

Merumuskan wewenang dan tanggung jawab yang harus dicapai oleh organisasi ditetapkan dengan standar atau tolak ukur yang telah disepakati oleh karyawan dan pimpinan. Manusia (karyawan) adalah makhluk sosial yang tidak bisa hidup sendiri, satu sama lain saling membutuhkan dan kerjasama merupakan bagian yang takkan terpisah dalam kehidupan dan manusia juga sebagai makhluk individualis yang mempunyai ego dan ambisi. Pemimpin merupakan bagian dari proses pengembangan sumber daya manusia, dimana sumber daya manusia merupakan asset dari sebuah organisasi atau perusahaan yang apabila dikelola secara tepat maka akan memberikan nilai tambah bagi perusahaannya.

Koperasi BMT EL-RAUSHAN merupakan lembaga ekonomi masyarakat yang bertujuan untuk mendukung kegiatan usaha ekonomi rakyat bawah dan kecil, yang dijalankan berdasarkan syariat Islam terkendala dengan adanya kenyataan di lapangan yang mengungkapkan bahwa SDM yang ikut terlibat di dalamnya baik sebagai anggota, pengurus, maupun pengelola koperasi kurang bisa mendukung jalannya koperasi. Sedangkan pengelola yang ditunjuk oleh pengurus seringkali diambil dari kalangan yang kurang profesional. Seringkali pengelola yang diambil bukan dari kalangan yang berpengalaman baik dari sisi akademis maupun penerapan dalam wirausaha melainkan dari orangorang yang kurang atau bahkan tidak mempunyai pekerjaan. Kondisi saat ini koperasi sedang mengalami kendala kepemimpinan yang kurang dapat memberikan contoh pada bawahan, pegawai yang kurang memiliki semangat kerja..

Kinerja karyawan yang optimal, yang baik adalah kinerja yang dapat diukur dengan aspek kuantitatif yang menggambarkan proses kerja karyawan yang mendapatkan support dari perusahaan, kondisi pekerjaan yang mendukung, mampu menyelesaikan tugas dengan cepat dan baik, jumlah kesalahan dapat diminimalisir, kemampuan sumber daya yang memenuhi harapan serta kualitas pekerjaan yang optimal. Disamping itu aspek kualitatif juga memegang peranan yang penting terutama tentang kualitas pekerjaan yang dihasilkan, ketepatan waktu, kemampuan dan keterampilan bekerja serta kemampuan mengevaluasi dalam organisasi. Menurut A.A. Prabu Mangkunegara (2010:9) "Merupakan perbandingan antara hasil yang dicapai dengan peran serta tenaga kerja dalam persatuan".

Pengelolaan terhadap sumber daya manusia menurut Handoko (2010: 195) "Merupakan hal yang penting dalam pencapaian tujuan". Umumnya pimpinan perusahaan mengharapkan kinerja yang baik dari 
masing-masing karyawan dalam mengerjakan tugas-tugas yang diberikan sebuah perusahaan. Perusahaan menyadari bahwa sumber daya manusia merupakan modal dasar dalam proses pembangunan perusahaan bahkan nasional, oleh karena itu kualitas sumber daya manusia senantiasa harus dikembangkan dan diarahkan agar tercapainya tujuan yang telah ditetapkan oleh suatu perusahaan atau organisasi.

Berdasarkan pengamatan pra riset yang peneliti lakukan terdapat beberapa kekurangan atau gap antara kondisi yang ideal serta kondisi riil yang ada dilapangan antara kinerja karyawan selama ini sebagai implementasi dari kekurangan antara factor kepemimpinan dan motivasi kerja karyawan yang ada. Hal ini didukung dengan beberapa penilaian internal yang dilakukan oleh koperasi dimana pencapaiannya tidak selalu memenuhi harapan yang ditetapkan.

Rendahnya etos kerja ini selain berkaitan dengan rendahnya kualitas SDM juga bisa disebabkan karena kurang adanya rangsangan untuk meningkatkan gairah kerja para personel yang terlibat dalam kegiatan koperasi sendiri. Secara organisasi anggota koperasi (yang hanya sebatas sebagai anggota saja) hanya punya andil dalam pengumpulan modal baik itu berasal dari simpanan pokok, simpanan wajib atau simpanan lainnya. Namun di sisi lain yang bertanggung jawab dan banyak mengeluarkan keringat dan pikiran adalah para personel yang terlibat dalam pengelolaan koperasi mulai dari pengawas, pengurus, ataupun pengelolanya (manajer).
Faktor

kepemimpinan, motivasi yang dimiliki seseorang adalah merupakan potensi, dimana seseorang belum tentu bersedia untuk mengerahkan segenap potensi yang dimilikinya untuk mencapai hasil yang optimal, sehingga masih diperlukan adanya pendorong agar seorang karyawan mau menggunakan seluruh potensinya. Daya dorong tersebut sering disebut motivasi. Melihat kenyataan tersebut, sudah saatnya pimpinan dapat memberikan kesempatan kepada karyawannya mengembangkan sumber daya manusia agar lebih berprestasi dalam melaksanakan tugasnya.

Di dalam mengelola karyawan yang ada di dalam perusahaan harus diciptakan suatu komunikasi kerja yang serasi dan selaras. Hal ini dapat meningkatkan semangat dan kegairahan kerja para karyawan tersebut dan diharapkan akan mencapai prestasi yang tinggi dibidang pekerjaan masing-masing. Kepemimpinan dan kepengikutan merupakan dua hal yang berbeda, namun kedua hal tersebut samasama penting dalam suatu perusahaan, Kepengikutan atau followership berarti seseorang yang menjadi pengikut.

Menurut Stephen P. Robbins dan Mary Coulter (2012:488) "Sangat penting bagi pemimpin untuk komitmen dalam melakukan pekerjaan secara maksimal dan terkoordinasi dengan baik". Hal ini pekerjaan dapat didelegasikan kepada bawahan serta mampu diimplementasikan kedalam kerja teamwork yang baik, karena jika seorang pemimpin tidak memiliki jiwa kepemimpinan maka hal 
tersebut akan menimbulkan resistensi dan dampak yang kurang baik bagi pertumbuhan perusahaan karena kepemimpinan merupakan apa yang pemimpin lakukan dalam proses memimpin kelompok dan mempengaruhinya untuk mencapai tujuan.

Demikian pula penilaian motivasi juga sangat penting dilakukan mengingat motivasi dapat mendorong seseorang dapat dengan senang hati melakukan pekerjaannya dengan baik. Dari hasil evaluasi kinerja pegawai dapat diketahui apakah seorang pegawai dapat bekerja dengan baik atau tidak yang dilihat dari kategori penilaian yang dibandingkan antara tolok ukur penilaian kinerja organisasi dengan kinerja pegawai. Sehingga dapat diartikan bahwa penilaian yang semakin tinggi menjadi indikasi bahwa kinerja pegawai tersebut mampu memenuhi harapan kinerja organisasi.

Berdasarkan wawancara dengan manager Koperasi BMT ELRAUSHAN ada beberapa masalah yang dapat berpengaruh terhadap kinerja karyawan diantaranya beban kerja dan kepuasan kerja. Dari hasil pra riset yang dilakukan, perihal kinerja pada Koperasi BMT ELRAUSHAN menunjukkan trend yang cenderung menurun.

$$
\text { Menurut A.A. Prabu }
$$

Mangkunegara (2010:9) "Dalam melakukan pekerjaan, faktor kepuasan kerja merupakan salah satu faktor yang dapat menurunkan maupun meningkatkan kinerja karyawan. Kinerja karyawan merupakan perbandingan antara hasil yang dicapai dengan peran serta tenaga kerja dalam persatuan".
Dalam mengelola sebuah organisasi, gaya kepemimpinan tentu tidak semua aspek yang diperlukan dapat terpenuhi, demikian pula dengan motivasi kerja yang ada pada masing-masing individu serta kinerja yang optimal. Prinsip "The right man in the right place" harus dipenuhi agar perusahaan dapat berjalan dengan efisien dan efektif. Jadi ada korelasi antara kepemimpinan, motivasi kerja dan kinerja karyawan, dimana ketiganya mampu menyelaraskan kekuatan individu dan pengelolaan sumber daya lainnya untuk mencapai tujuan organisasi/perusahaan.

\section{Perumusan Masalah}

1. Bagaimana pengaruh kepemimpinan terhadap kinerja karyawan secara parsial di Koperasi BMT EL-RAUSHAN?.

2. Bagaimana pengaruh motivasi kerja terhadap kinerja karyawan secara parsial di Koperasi BMT EL-RAUSHAN?

3. Seberapa besar pengaruh kepemimpinan dan motivasi kerja secara simultan terhadap kinerja karyawan di Koperasi BMT ELRAUSHAN?

\section{KAJIAN TEORI}

\section{A. Kepemimpinan}

Kepemimpinan menurut Suwatno dan Doni Juni Priansa (2011:159), "Merupakan apa yang pemimpin lakukan dalam proses memimpin kelompok dan mempengaruhinya untuk mencapai tujuan". Lebih lanjut diterangkan indikator kepemimpinan meliputi : a) Memiliki pengaruh yang baik (pemimipin harus dapat menjadi contoh), b) Mampu menumbuhkan 
motivasi, c) Menumbuhkan ransangan untuk memunculkan ide dan gagasan d) Mampu memberikan perhatian, mendengarkan keluhan, dan mengerti kebutuhan karyawannya.

\section{B. Motivasi Kerja}

Motivasi kerja menurut McClelland yang diterjemahkan Miftah Toha (2012:235) adalah "Seperangkat kekuatan baik yang berasal dari dalam diri maupun dari luar diri seseorang yang mendorong untuk memulai berperilaku kerja sesuai dengan format, arah, intensitas dan jangka waktu tertentu". Lebih lanjut diterangkan indikator motivasi kerja meliputi : a) Kebutuhan untuk berprestasi (Need of Achievement), b) Kebutuhan untuk berkuasa/mempengaruhi orang lain (Need of Power) dan c) Kebutuhan berafiliasi (Need of Affilliation).

\section{Kinerja Karyawan}

Kinerja karyawan menurut A.

A. Prabu Mangkunegara (2010:9) "Merupakan perbandingan antara hasil yang dicapai dengan peran serta tenaga kerja dalam persatuan". Adapun indikator dari kinerja karyawan meliputi: a) Aspek kuantitatif dan b) Aspek kualitatif.

\section{METODE PENELITIAN}

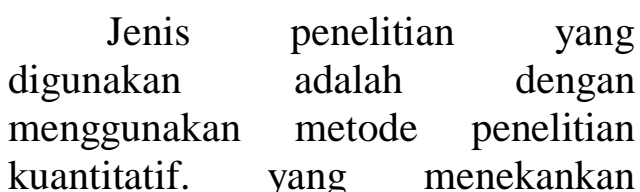
analisisnya pada data-data numerikal (angka) yang selanjutnya diolah dengan metode statistika. Penelitian ini merupakan penelitian penjelasan asosiatif yang menguji hubungan kausal antara variabel independen yaitu kepemimpinan dan motivasi kerja, variabel dependen yaitu kinerja karyawan.

Populasi dalam penelitian ini adalah karyawan Koperasi BMT ELRAUSHAN dengan jumlah sampel 100 orang. Teknik pengambilan sampel yang digunakan adalah teknik probability sampling.

Pengujian data digunakan uji instrumen, uji kelayakan data, uji regresi, uji koefisien determinasi dan uji hipotesis dengan uji t dan uji $\mathrm{F}$.

\section{HASIL PENELITIAN DAN PEMBAHASAN \\ Uji Validitas (Uji Instrumen)}

Dari data tabel di atas, dapat dilihat bahwa dari 10 butir pernyataan variabel kepemimpinan $\left(\mathrm{X}_{1}\right)$ semua butir pernyataan dinayatakan valid, dimana semua item-item pernyataan memiliki nilai corrected item total correlation lebih besar dari 0,30.

\section{Uji Reliabilitas}

Tabel 4.1

Uji Reliabilitas

\begin{tabular}{|c|c|c|c|}
\hline Variabel & $\begin{array}{c}\text { Coeficient } \\
\text { Alpha }\end{array}$ & $\begin{array}{c}\text { Standar } \\
\text { Chronbach } \\
\text { Alpha }\end{array}$ & Kesimpulan \\
\hline $\mathrm{X} 1$ & 0.759 & 0,60 & Reliabel \\
\hline $\mathrm{X} 2$ & 0.687 & 0,60 & Reliabel \\
\hline $\mathrm{Y}$ & 0.700 & 0,60 & Reliabel \\
\hline
\end{tabular}

Berdasarkan hasil uji reliabilitas pada tabel di atas, dapat diketahui bahwa seluruh variabel yang digunakan dinyatakan reliablel, karena masingmasing variabel memiliki nilai coeficien Alpha lebih besar dari Chronbach Alpha 0,60.

\section{Uji Asumsi Klasik (Uji Prasyarat) Uji Normalitas}

Tabel 4.2 
Uji Normalitas

\begin{tabular}{|c|r|r|r|}
\hline & \multicolumn{3}{|c|}{ Kolmogorov-Smirnov ${ }^{\mathrm{a}}$} \\
\cline { 2 - 4 } & Statistic & df & \multicolumn{1}{c|}{ Sig. } \\
\hline $\begin{array}{c}\text { Kinerja } \\
\text { Pegawai (Y) }\end{array}$ & .978 & 100 & .086 \\
\hline
\end{tabular}

Data tabel di atas, test of normality Kolmogorof-Smirnof diperoleh nilai signifikansinya sebesar $\alpha=0,086$, dimana nilai tersebut lebih besar dari nilai 0,050 . Dengan demikian asumsi distribusi persamaan pada uji ini adalah normal.

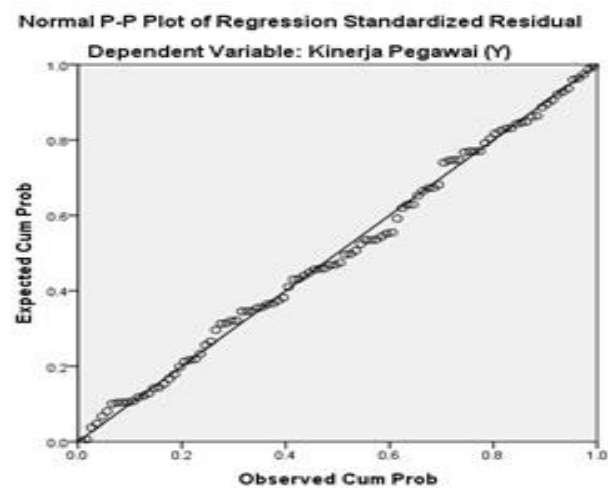

Gambar 4.1 P-Plot

Pada gambar grafik diatas dapat dilihat bahwa grafik normal probability plot menunjukkan pola grafik yang normal. Hal ini terlihat dari titik-titik yang menyebar disekitar grafik normal dengan titiktitik yang menyebar disekitar garis diagonal. Dengan penyebaran yang mengikuti alur garis diagonal tersebut maka dapat disimpulkan bahwa model regresi layak dipakai karena memenuhi asumsi normalitas.

\section{Uji Heteroskedastisitas dengan Uji Glejser}

Tabel 4.3

Uji Gletser Coefficients $^{\mathrm{a}}$

\begin{tabular}{|l|c|c|c|c|}
\hline & $\begin{array}{c}|c| \\
\text { Unstandardiz } \\
\text { ed } \\
\text { Coefficients }\end{array}$ & $\begin{array}{c}\text { Standardiz } \\
\text { ed } \\
\text { Coefficien } \\
\text { ts }\end{array}$ & & \\
Model & Sig & \\
\hline
\end{tabular}

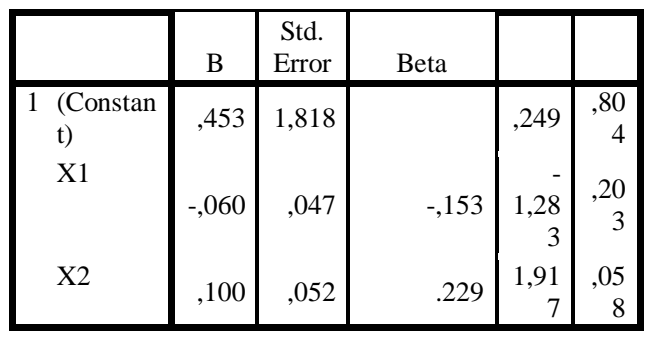

Pada gambar diatas, glejser test model pada variabel kepemimpinan (X1) diperoleh nilai probability signifikansi (Sig.) sebesar 0,203 dan motivasi kerja (X2) diperoleh nilai probability signifikansi (Sig.) sebesar 0,058 di mana keduanya nilai signifikansi (Sig.)> 0,05. Dengan demikian regression model pada data ini tidak ada gangguan heteroskesdastisitas, sehingga model regresi ini layak dipakai sebagai data penelitian.

\section{Uji Multikolinearitas}

Tabel 4.4

Uji Multikolinearitas

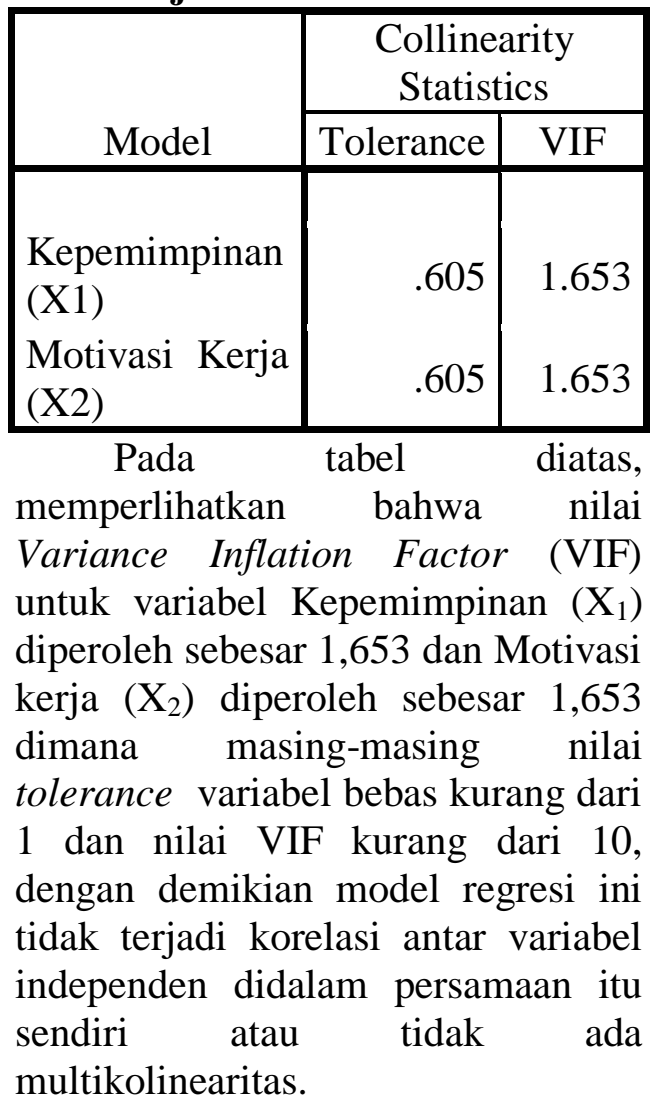




\section{Uji Autokorelasi}

Tabel 4.5

Uji AutoKorelasi

\begin{tabular}{|c|c|r|r|}
\hline Model & \multicolumn{1}{|c|}{$\mathrm{R}$} & $\begin{array}{c}\mathrm{R} \\
\text { Square }\end{array}$ & $\begin{array}{c}\text { Durbin- } \\
\text { Watson }\end{array}$ \\
\hline 1 & $\begin{array}{r}.69 \\
4^{\mathrm{a}}\end{array}$ & .482 & 1.971 \\
\hline
\end{tabular}

Dari tabel diatas, diperoleh nilai Durbin-Watson sebesar 1.971 dan berada diantara $(1,550-2,460)$ sesuai dengan ketentuan maka model regresi ini tidak ada autokorelasi.

\section{Analisis Regresi Linier Berganda Tabel 4.6}

Analisis Regresi Linier Berganda Coefficients

\begin{tabular}{|c|c|c|c|c|c|}
\hline \multirow[b]{2}{*}{ Model } & \multicolumn{2}{|c|}{$\begin{array}{c}\text { Unstandardiz } \\
\text { ed } \\
\text { Coefficients }\end{array}$} & \multirow{2}{*}{$\begin{array}{c}\begin{array}{c}\text { Standardiz } \\
\text { ed } \\
\text { Coefficien } \\
\text { ts }\end{array} \\
\text { Beta }\end{array}$} & \multirow[b]{2}{*}{$\mathrm{t}$} & \multirow[b]{2}{*}{ Sig } \\
\hline & B & $\begin{array}{c}\text { Std. } \\
\text { Error }\end{array}$ & & & \\
\hline $\begin{array}{ll}1 \text { (Consta } \\
\text { nt) }\end{array}$ & $\begin{array}{r}11,55 \\
7\end{array}$ & 2,932 & & $\begin{array}{r}3,94 \\
2\end{array}$ & $\begin{array}{r}.00 \\
0\end{array}$ \\
\hline $\mathrm{X} 1$ & ,274 & ,076 & ,317 & $\begin{array}{r}3,60 \\
8\end{array}$ & $\begin{array}{r}.00 \\
0\end{array}$ \\
\hline $\mathrm{X} 2$ & ,448 & ,084 & ,467 & $\begin{array}{r}5,31 \\
7\end{array}$ & $\begin{array}{r}.00 \\
0\end{array}$ \\
\hline
\end{tabular}

Berdasarkan hasil perhitungan regresi pada tabel di atas, diperoleh persamaan regresinya $\mathrm{Y}=11,557+$ $0,274 X_{1}+0,448 X_{2}$.

\section{Pengaruh Secara Parsial}

Untuk mengetahui pengaruh variabel kepemimpinan $\left(\mathrm{X}_{1}\right)$ terhadap kinerja karyawan (Y) serta variabel motivasi kerja $\left(\mathrm{X}_{2}\right)$ terhadap kinerja karyawan (Y) secara parsial digunakan analisis koefisien determinasi. Adapun tingkat hubungan secara parsial tersebut hasil analisisnya sebagai berikut:

Tabel 4.7

Pengaruh X1 terhadap Y

\begin{tabular}{|c|c|c|c|c|}
\multicolumn{5}{|c|}{ Model Summary } \\
Model & $\mathrm{R}$ & $\begin{array}{c}\mathrm{R} \\
\text { Square }\end{array}$ & $\begin{array}{c}\text { Adjusted } \\
\text { R Square }\end{array}$ & $\begin{array}{c}\text { Std. Error of } \\
\text { the Estimate }\end{array}$ \\
\hline
\end{tabular}

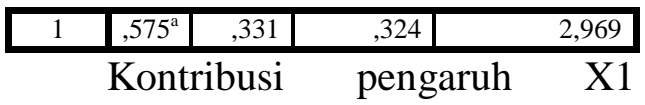

terhadap Y adalah sebesar 33,1\%.

Tabel 4.8

Pengaruh X2 terhadap Y

\begin{tabular}{|c|c|r|r|r|}
\hline Model & $\mathrm{R}$ & $\begin{array}{c}\text { R } \\
\text { Square }\end{array}$ & $\begin{array}{c}\text { Adjusted } \\
\text { R Square }\end{array}$ & $\begin{array}{c}\text { Std. Error of } \\
\text { the Estimate }\end{array}$ \\
\hline 1 &, $642^{\mathrm{a}}$ &, 412 &, 406 & 2,782 \\
\hline
\end{tabular}

Kontribusi pengaruh X2 terhadap Y adalah sebesar $41,2 \%$.

\section{Analisis Koefiisien Determinasi}

Koesfisien Determinasi dipergunakan untuk mengetahui presentase pengaruh secara simultan variabel X1 dan X2 terhadap Y.

Tabel 4.9

Analisis Koefiisien Determinasi

Model Summary

\begin{tabular}{|c|c|r|r|r|}
\hline Model & $\mathrm{R}$ & $\begin{array}{c}\mathrm{R} \\
\text { Square }\end{array}$ & $\begin{array}{c}\text { Adjusted } \\
\text { R Square }\end{array}$ & $\begin{array}{c}\text { Std. Error of } \\
\text { the Estimate }\end{array}$ \\
\hline 1 &, $694^{\mathrm{a}}$ &, 482 &, 471 & 2,626 \\
\hline
\end{tabular}

Besarnya kontribusi pengarih secara simultan adalah sebesar 48,2\%

\section{Pengujian Hipotesis \\ Uji Parsial (t hitung)}

Tabel 4.10

Pengaruh Kepemimpinan $\left(\mathbf{X}_{1}\right)$

Terhadap Kinerja Pegawai (Y)

\begin{tabular}{|l|r|r|r|c|}
\hline \multirow{2}{*}{ Model } & \multicolumn{1}{|c|}{ Unstandardized Coefficients } & \multirow{2}{*}{ B } & Std. Error & \multicolumn{1}{c|}{ Sig. } \\
\cline { 2 - 3 } 1 (Constant) & 20,272 & 2,749 & 7,374 & .000 \\
X1 &, 497 &, 071 & 6,963 & .000 \\
\hline
\end{tabular}

Dari analisis statistik diperoleh nilai $t_{\text {hitung }}>t_{\text {tabel }}(6,963>1,984)$, hipotesis pertama yang menyatakan terdapat pengaruh yang positif dan signifikan secara parsial antara kepemimpinan terhadap kinerja pegawai dapat diterima.

Tabel 4.11

Pengaruh Motivasi Kerja $\left(\mathbf{X}_{2}\right)$ Terhadap Kinerja Pegawai (Y)

\begin{tabular}{|c|c|c|c|c|}
\hline \multirow[b]{2}{*}{ Model } & \multicolumn{2}{|c|}{$\begin{array}{c}\text { Unstandardized } \\
\text { Coefficients }\end{array}$} & \multirow[b]{2}{*}{$\mathrm{t}$} & \multirow[b]{2}{*}{ Sig. } \\
\hline & B & Std. Error & & \\
\hline 1 (Constant) & 15,542 & 2,878 & 5,400 & .000 \\
\hline $\mathrm{X} 2$ & 616 & ,074 & 8,294 & .000 \\
\hline
\end{tabular}


Dari analisis statistik diperoleh nilai $t_{\text {hitung }}>t_{\text {tabel }}(8,294>1,984)$, hipotesis kedua yang menyatakan terdapat pengaruh yang positif dan signifikan secara parsial antara motivasi kerja terhadap kinerja pegawai dapat diterima.

\section{Uji F (Simultan)}

\section{Tabel 4.12}

\begin{tabular}{|rl|r|r|c|c|}
\multicolumn{5}{c|}{ Uji F } \\
\hline & Model & \multicolumn{1}{c|}{ df } & $\begin{array}{c}\text { Mean } \\
\text { Square }\end{array}$ & F & Sig. \\
\hline 1 Regression & 2 & 311,106 & 45,122 & $.000^{b}$ \\
& Residual & 97 & 6,895 & & \\
Total & 99 & & & \\
\hline
\end{tabular}

Dari analisis statistik diperoleh nilai $F_{\text {hitung }}=45,122>2,700$, hipotesis ketiga yang menyatakan terdapat pengaruh positif dan signifikan secara simultan antara kepemimpinan dan motivasi kerja terhadap kinerja pegawai dapat diterima.

\section{KESIMPULAN DAN SARAN}

\section{A. Kesimpulan}

Dari analisis uji pengaruh dengan regresi, disimpulkan bahwa secara parsial maupun secara simultan variabel kepemimpinan memiliki pengaruh yang positif dan signifikan terhadap kinerja karyawan dengan dibuktikan pengujian hipotesis yang menyatakan variabel independen berpengaruh terhadap variabel dependen dapat diterima.

\section{B. Saran}

Kriteria jawaban responden dari masing-masing variaben menunjukkan perolehan score yang baik, namun untuk lebih baik lagi manager koperasi harus memperhatikan suasana kerja yang baik, karena dapat menciptakan lingkungan yang saling menghargai sehingga karyawan akan merasa tenang dalam bekerja, yang akhirnya karyawan semakin memiliki kinerja yang lebih baik.

\section{DAFTAR PUSTAKA}

Agung Nugroho, "Strategi Jitu memilih Metode Statistik Penelitian Dengan SPSS", Andi Ofset, Yogyakarta, 2008.

Anaroga, Pandji, "Bumn, Swasta dan Koperasi”, Gramedia Utama, Jakarta, 2009.

Arikunto, Suharsimi, "Prosedur Penelitian Suatu Pendekatan Praktek", PT. Rineka Cipta, Jakarta, 2010.

Bambang Kusriyanto, "Manajemen Sumber Daya Manusia", Sulita, bandung, 2010.

Ghozali, Imam, "Aplikasi Analisis Multivariate dengan Program SPSS”, Edisi Kelima, Badan Penerbit Undip, Semarang, 2011

Kartono, Kartini, "Pemimpin dan Kepemimpinan”, Edisi Kedua, Cetakan Kesembilan, RajaGrafindo Persada, Jakarta, 2011.

Mangkunegoro, Anwar Prabu, "Evaluasi Kinerja Sumber Daya Manusia", Refika Aditama, Bandung, 2010.

Raymond A. Noe, "Human Resources Management, Gaining Copetitive Advantage" Edisi ketiga, Mc Graw-Hill, 2010.

Robbins, Stephen dan Mary Coulter, "Manajemen", PT. Indeks Kelompok Gramedia, Jakarta, 2012. 
Salam, Darma Setyawan, "Manajemen Pemerintahan Indonesia", Djambatan, Jakarta, 2007.

Sugiyono, "Metode Penelitian Kuantitatif Kualitatif dan $R$ \& $D$ ”, Penerbit CV. Alfabeta, Bandung, 2014.

Sunarsi, D. (2018). Pengaruh Gaya Kepemimpinan, Motivasi Dan Disiplin Kerja Terhadap Kinerja Pendidik Yayasan Marvin. Inovasi, 5(1), 1-18.
Santoso, Singgih, "SPSS Statistik Parametik" Cetakan Kedua, PT. Elek Media, 2009.

Syofian, Siregar, "Stattistika Deskriptif Untuk Penelitian", Rajawali Pers, Jakarta, 2010.

Terry, George R \& Rue, Leslie W. Rue, "Dasar-Dasar Manajemen", Jakarta Bumi Aksara, Jakarta, 2010.

Thoha, Miftah, "Kepemimpinan Dalam Manajemen”, Edisi Pertama, PT. Raja Grafindo, Jakarta, 2012. 